\title{
JAK LICZĄ POLACY - LINGWAKULTUROWE ASPEKTY GRAMATYKI OPISOWEJ I HISTORYCZNEJ LICZEBNIKA
}

\begin{abstract}
Słowa kluczowe: lingwakultura, gramatyka liczebnika, glottodydaktyka kulturowa, nauczanie, antropometria

Streszczenie. Artykuł jest poświęcony wybranemu zagadnieniu nauczania cudzoziemców jpjo - gramatyce liczebnika. Eksponuje problem dwojakiego wyrażania mnogości w konstrukcjach zdaniowych. Wskazana jest nie tylko gramatyczna wykładnia tego zagadnienia, gdzie nominalność użytych liczebników (mniejszych lub większych niż 5) decyduje o mianownikowej bądź dopełniaczowej konstrukcji zdania. Obok neurolingwistycznej interpretacji takiego mechanizmu, w tekście prowadzone są lingwakulturowe rozważania, stanowiące jego istotę. Pojawia się wyjaśnienie antropometryczne i historia tworzenia się istniejącej obecnie zasady językowej. Dodatkowo tekst stanowi swoistą propozycję interdyscyplinarnej narracji w nauczaniu polszczyzny.
\end{abstract}

Gramatyka liczebnika nastręcza uczącym się języka polskiego cudzoziemcom sporo trudności. W jej obrębie pierwszym, znaczącym problemem jest rozpoznawanie gramatycznych wyróżników liczby mnogiej w konstrukcjach zdaniowych, w których pojawia się - lub nie - liczebnik. Nie należy zresztą twierdzić, że chodzi tutaj jedynie o trudność gramatyczną. Ta ogranicza się głównie do konieczności poznania kilku końcówek fleksyjnych, zmieniających się w zgodzie z deklinacją oraz opisu reguł dotyczących kategorii męskoosobowej, naddanej niejako do obecnej w polszczyźnie asymetrii rodzajowej. Znacznie większym wyzwaniem jest zrozumienie, dlaczego w tym języku logika wyrażania mnogości kończy się na granicy liczebników między cztery a pięć. Dlaczego jest tak, że jedynie liczebniki $d w a, t r z y, c z t e r y$ informują nas formalnie o ilości większej niż jeden? W konsekwencji czego, obecność liczebnika w zdaniu znacząco utrudnia rozpoznawanie wyznaczników mnogości. Jej postać jest zależna od podanej liczby. Tylko w zdaniach, w których występują trzy wymienione liczby, czasowniki,

“p.garncarek@uw.edu.pl, Uniwersytet Warszawski, Wydział Polonistyki, Centrum Języka Polskiego i Kultury Polskiej dla Cudzoziemców POLONICUM, ul. Krakowskie Przedmieście 26/28, 00-927 Warszawa, ORCID: 0000-0002-7664-7535. 
rzeczowniki, przymiotniki i zaimki użyte są w liczbie mnogiej. Dla cudzoziemca jest jasne, że skoro w zdaniu informującym o sytuacji jednostkowej padają użyte $\mathrm{w}$ liczbie pojedynczej wyrazy np.: ten, jeden, stary, dom, stoi..., to w podobnym zdaniu, ale informującym o mnogości / wielości obiektów, osób lub zdarzeń, powinny pojawić się wyrazy użyte w liczbie mnogiej np.: te, dwa, stare, domy, stoją... Dalej jednak nie jest już tak prosto - i to z dwóch powodów. Po pierwsze, należy zmienić konstrukcję zdania z mianownikowej na dopełniaczową np.: jedna stara lampa, cztery stare lampy, ale pięć starych lamp. A po drugie, użyć czasownika wskazującego nie wiedzieć czemu ponownie na liczbę pojedynczą, co kłóci się z logiką samej wypowiedzi np.: jest jeden dom, sa trzy domy, ale jest pięć domów. Odkładając na później (a zazwyczaj całkiem) tłumaczenie przyczyny takiego stanu rzeczy, staramy się zautomatyzować i przećwiczyć powstające konstrukcje zdaniowe, powtarzając naprzemiennie, w jakich sytuacjach sięgamy po dopełniacz, a w jakich po czasownik jest, na wyrażanie liczby mnogiej.

* To jest jeden problem (mianownik).

* To sa dwa, trzy, cztery problemy (mianownik).

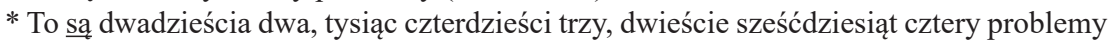
(mianownik).

* To jest pięć, sześć, problemów (dopełniacz).

* To jest siedemset pięć, milion siedemnaście problemów (dopełniacz).

* To jest dwadzieścia jeden, sto jeden problemów (dopełniacz).

Dodatkową trudność stanowią tutaj ciągi liczbowe, a raczej występujące na ich końcu cyfry, które determinują konstrukcje gramatyczne wypowiedzi. Wszystko to stanowi wystarczające nagromadzenie powodów utrudniających automatyzację użyć. W praktyce glottodydaktycznej nie można więc przecenić dobrodziejstwa różnorodności ćwiczeń i mnogości przykładów, poświęconych temu zagadnieniu. Nie powinny być one zależne od stopnia zaawansowania uczących się, czy programów realizowanych na wszystkich poziomach kompetencyjnych, ale pojawiać się od samego początku nauczania aż po jego kres.

To są studenci. (mianownik)

To jest sześciu studentów. (dopełniacz)

To są zegarki. (mianownik)

Tu jest siedem zegarków. (dopełniacz)

Tu są tylko kobiety. (mianownik)

Tu jest pięć kobiet. (dopełniacz)

Tu są jeziora. (mianownik)

Tu jest ponad trzydzieści jezior. (dopełniacz)

To są istotne problemy. (mianownik)

To jest tysiąc problemów. (dopełniacz)

1. To są bardzo piękne kobiety.

- To są (3)

- To jest (6) 
2. To są moi kuzyni z Kozienic.

- To sa $(2)$

- To jest (5)

3. To sa byłe narzeczone Waldemara.

- To są (4)

- To jest (8)

4. To są kilogramy nadwagi.

- To $\underline{\text { sa }}(22)$.....

- To jest (11)

Skoro uzmysłowimy uczącym się, że pozostałe liczby (począwszy od 5) informują inaczej o liczbie mnogiej i wymagają użycia formy dopełniacza dla wszystkich pojawiających się w zdaniu odmiennych części mowy, to pozostaje nam jedynie wyjaśnić, dlaczego tak się dzieje. Nie do końca i nie wszystkich przekonuje neurolingwistyczna interpretacja, opierająca się na wrażeniach wzrokowych. Te sprawiają, że kiedy wchodzimy do jakiegoś pomieszczenia, widzimy albo zbiór łatwo policzalny np.: dwie, trzy, cztery studentki (psy, książki itd.), albo grupę / zbiór o liczbie elementów niedających się momentalnie policzyć. Dlatego w tym drugim wypadku sięgamy po użycie czasownika w liczbie pojedynczej, wskazując, że: Tu jest mała / duża grupa (kogo? czego?) pięciu studentek. Co w przekładzie na języki komentarza brzmi np.: Here is a small group of students (ang.) lub Hier ist eine kleine Gruppe von Studentinnen (niem.) i daje pewne wyobrażenie o opisywanych zależnościach. Takie odwołanie do pojęcia grupy sprawdza się w praktyce glottodydaktycznej, kiedy w grę wchodzą ciągi liczbowe, a zwłaszcza liczebniki o wielkościach 11 - 19, gdzie morfem -naście daje się tłumaczyć jako wyróżnik grupy np.: Tu jest kilkanaście nowych studentek. Znacznie ciekawsze wydaje się być wyjaśnienie nawiązujące do antropometrii - metody badawczej stosowanej w antropologii fizycznej, ale dającej wywieść się z obszarów wiedzy o kulturze. Takie interdyscyplinarne podejście do gramatycznego w założeniu zagadnienia, jeśli tylko nadać mu przemyślany scenariusz lekcji, pozwala na redukowanie wywodu o samym języku na rzecz ciekawej tematycznie narracji prowadzonej przy jego użyciu. Można więc wywód taki zacząć od informacji o wspomnianej antropometrii, traktującej o sposobach i zwyczajach dokonywania porównawczych pomiarów przy wykorzystywaniu części własnego ciała. Ten podyktowany koniecznością sposób relatywizowania się z otaczającą nas rzeczywistością towarzyszył ludzkości od zawsze i był obecny we wszystkich znanych kulturach. Takie „mierzenie świata” odbywało się i ciągle jeszcze odbywa z wykorzystaniem: długości kończyn, dłoni, rozstawu palców, stóp, rozpiętości ramion, garści, łokci, ale też ciepłoty ciała, rytmu serca, objęcia, zasięgu wzroku czy głosu. Dla potrzeb niniejszego wywodu wystarczy nam odziedziczona po przodkach umiejętność liczenia na palcach, do dziś stosowana przy dokonywaniu prostych obliczeń matematycznych na poziomie wiedzy przedszkolnej i wczesnoszkolnej. Onegdaj dokonywano prostych transakcji handlowych, trzymając 
(zabezpieczając / eksponując) towar w jednej ręce, a palce drugiej wykorzystując do wskazań liczbowych. Zasada ta nie naprowadza nas jednak bezpośrednio na wyjaśnienie opisywanego problemu gramatycznego. Wszak posiadamy pięć palców u każdej ręki, więc granica postrzegania powinna być nie między wartościami 4-5, lecz 5-6. Na tym etapie rozważań można podążyć tropem antropologicznym skierowanym bardziej nieco na kulturę materialną i zaproponować rozważania nad historią i przeznaczeniem - naparstka. Ten użyteczny i do niedawna jeszcze powszechnie używany przedmiot to zwykły kapturek ochronny nakładany na palec podczas szycia. Zabezpiecza przed ukłuciem się igłą podczas wbijania jej w twardy materiał. Najstarszy naparstek (wykonany z brązu) znaleziono w Pompejach. Pochodził z I wieku n.e. Prawdopodobnie najstarszy naparstek w Polsce (i jeden z najstarszych w Europie) ma również około 2000 lat. Zrobiono go z gliny. Został znaleziony wśród pozostałości chat kultury łużyckiej. Najczęściej naparstki wykonywane były z metalu, gumy, skóry, szkła, drewna oraz porcelany. Dawniej robiono je też niekiedy z kości, rogów albo srebra. Bywały misternie zdobione i profilowane. Nadawano im więc walory estetyczne i czyniono przedmiotami wartościowymi. Ten nieprzypadkowy, jak się później okaże, wywód o naparstku należy uzupełnić o dodatkową informację. Taką mianowicie, że potocznie naparstkiem nazywa się również niewielką jednostkę objętości. Pojęcie to pochodzi z początków XIX wieku, gdy naparstki stosowano jako miarki do mocnego alkoholu. Były więc czymś w rodzaju małych misternie wykonanych kieliszków dających się z łatwością trzymać w palcach. Leksem naparstek wydaje się być dość inspirujący ze słowotwórczego punktu widzenia. Jednoznacznie nazywa przedmiot nakładany na coś. I właśnie o to „coś” nam chodzi. Ponieważ mowa tutaj o funkcji ochronnej palca, nasz naparstek powinien nazywać się * $\underline{n a-}$ palcznik. Taki mechanizm tworzenia nazw przedmiotów nakładanych na różne części ludzkiego ciała ma szereg egzemplifikacji:

* naramiennik - ochraniacz lub ozdoba nakładana na ramiona żołnierza lub sportowca;

* nagolennik - ochraniacz nakładany na goleń (nogę) sportowca (dawniej też wojownika);

* napierśnik - ochraniacz, część zbroi nakładanej na klatkę piersiową wojownika;

* naszyjnik - ozdoba zawieszana na szyi;

* nausznik - ochraniacz lub ozdoba uszu;

* nausznica - ozdoba uszu, rodzaj biżuterii.

$\mathrm{Na}$ co w takim razie nasi przodkowie nakładali naparstki? By odpowiedzieć na to pytanie, należy znacząco cofnąc się w czasie historycznym, do okresu, w którym mianem palec określano tylko kciuk. Cztery pozostałe nazywano inaczej. Skąd zatem zmiana nazwy? Z ustaleń etymologicznych wynika, że chodzi o rodowód, a więc i źródłosłów chrześcijański. Słowo kciuk pochodzi bowiem od słowa kszciuk oznaczającego palec, którym namaszcza się czoło dziecka podczas chrztu. Co łatwo ustalić za takimi opracowaniami, jak chociażby Stownik staropolski M. Arcta (1917), czy Stownik polszczyzny XVI w. (1919). 


\section{chrzcić $<$ krzcić $<$ kcici}

Co ciekawe, ten „neologizm” wywiedziony ze szczególnej, ale i nowej funkcji tego palca nie pojawił się w żadnym innym języku słowiańskim. Z tym zastrzeżeniem, że na prawosławnym obszarze słowiańszczyzny wschodniej kciuk jest wyróżniany w opisie językowym jako:

* вялікі палеи рукі (j. białoruski),

* большой палеи руки (j. rosyjski),

* великий палеиь руки (j. ukraiński).

Pojawił się za to w języku litewskim nykštys, z wyraźnym odniesieniem do obrządku chrztu krikštas. Podobnie zresztą jak w języku łotewskim ìkškiss, w którym sam chrzest to kristības.

To, że w języku staropolskim palec był jeden, ma liczne poświadczenia w takich określeniach jak:

* goty jak palec - w rozumieniu biedny lub bez ubrania;

* samotny jak palec - w rozumieniu sam, opuszczony, odludek...

W określanym na co najmniej XIII-wieczny tekście polskiej pieśni religijnej Oj, maluśki, maluśki, maluśki, odnajdujemy kolejny dowód:

Tam Ci zawsze stużyly, stużyly

prześliczne janioły;

A tu lezys Sam jeden, Sam jeden,

jako palec goty.

W dawnym języku polskim, w przeciwieństwie do kciuka, pozostałe palce nazywały się parsty lub pirsty. Co prowadzi do logicznego wniosku, że naparstek zakładaliśmy na parst. Tutaj raz jeszcze należy zagłębić się w etymologicznych opracowaniach słownikowych, poczynając od ustaleń Aleksandra Brücknera (1927), a kończąc na wszystkich kolejnych:

* prasłowiański pirst (stąd pierścionek),

* polski parst (stąd naparstek).

Warto przy tej okazji uzmysłowić sobie, że analogie leksykalne są znacznie szerszej natury i sięgają do większości języków bałtosłowiańskich, stąd:

* litewski pirsztas;

* pruski nagepirstis (palec u nogi);

* u wszystkich Słowian prst (palec), prsten;

* ruskie pierczatka (rękawiczka).

Nasi przodkowie oczywiście dokonywali swoich obliczeń na palcach, pozostając $\mathrm{w}$ zgodzie $\mathrm{z}$ antropometryczną zasadą relatywizowania się $\mathrm{z}$ otaczającą ich 
przestrzenią. Stąd po części wzięła się utrwalona we współczesnej polszczyźnie, a kłopotliwa dla uczących się jej cudzoziemców reguła, że:

* jeden palec = liczba pojedyncza,

* cztery parsty $=$ liczba mnoga.

O większych wartościach liczbowych można więc powiedzieć, że od zawsze znajdowały się poza zasięgiem ręki. Stąd ich wyobrażeniowe / zbiorowe, wyrażane dopełniaczowo w opisie gramatycznym postrzeganie.

To jednak nie koniec cudzoziemskich kłopotów z poprawnym wyrażaniem wartości liczbowych po polsku. Jak się bowiem okazuje, w języku tym należy brać pod uwagę nie tylko to, jak się liczy, ale też to, co lub kogo się liczy. I tak docieramy do kategorii męskoosobowej. Tutaj granicę logicznych skojarzeń należy przesunąć jeszcze dalej. Dla wielu cudzoziemców, zwłaszcza tych, posługujących się językami pozbawionymi kategorii osobowych (np. angielskim), pojawia się tu kilka „progów” zrozumienia. Po pierwsze, zmuszeni są ustalić, które rzeczowniki - przedmioty, zjawiska, emocje... - przynależą do poszczególnych rodzajów. Wbrew pozorom nie jest to czynność łatwa, chociażby dla osób niemieckojęzycznych. Nie jest też łatwa z powodu różnie wyrażanej w poszczególnych językach asymetrii rodzajowo-płciowej. Do tego należy wyodrębnić całkiem spory zbiór rzeczowników, które niejako „kłócą się” z kategorią gramatyczną rodzaju męskiego (np.: poeta, ekonomista, babsztyl). Dotarcie do drugiego „progu” trudności, czyli ustalenia inwentarzy rzeczowników przynależnych do kategorii męskiej, żeńskiej i nijakiej, nie jest więc ani łatwe, ani szybkie. Trzeci próg pojawia się w momencie wyjaśnień dotyczących niejednorodności kategorii męskiej:

* rodzaj męskoosobowy (profesor, lekarz, Adam, brat .....)

* rodzaj męskożywotny (pies, kot, koń, komar .....)

* rodzaj męskonieżywotny (adres, zegarek, dom, krawat .....)

Nawet jeśli uzasadnimy logiczną potrzebę posiadania w języku takich rozróżnień, to i tak staniemy przed zniechęcającą koniecznością nauki wielorakich odmian. Dla rzeczownika rodzaj jest przecież kategorią selektywną. Oznacza to, że ma on określony rodzaj gramatyczny. Rzeczowniki można wobec tego podzielić na grupy ze względu na ich rodzaj. Na przykład w liczbie pojedynczej rzeczownik dtugopis jest rodzaju męskiego i wobec tego należy do grupy rzeczowników rodzaju męskiego, książka jest rodzaju żeńskiego, a mleko - rodzaju nijakiego. W liczbie mnogiej rzeczownik dtugopisy jest rodzaju niemęskoosobowego, a leka$r z e$ - męskoosobowego. Rzeczownik nie odmienia się przez rodzaje (na przykład nie istnieje forma żeńska rzeczownika dtugopis). Rodzaje rzeczownika w liczbie pojedynczej i mnogiej klasyfikuje się, niestety, niezależnie. To właśnie stanowi, co poświadcza praktyka glottodydaktyczna, sporą trudność w trakcie przyswajania polszczyzny. Zanim więc wrócimy do wiodącego zagadnienia „liczenia po 
polsku", musimy poinformować cudzoziemców, a sobie samym przypomnieć, że żywotność odgrywa rolę w liczbie pojedynczej, natomiast osobowość (jakkolwiek to zabrzmi) w liczbie mnogiej. Tę ostatnią można całościowo zilustrować poniższą tabelą:

Tabela 1. Osobowość rzeczownika w liczbie mnogiej

\begin{tabular}{|c|l|l|l|}
\hline \multicolumn{1}{|c|}{ r. męskoosobowy } & $\begin{array}{c}\text { r. męskożywotny, } \\
\text { męskonieżywotny }\end{array}$ & \multicolumn{1}{|c|}{ r. żeński } & r. nijaki \\
\hline $\begin{array}{l}\text { dwaj / dwu (dwóch) } \\
\text { profesorowie / profesorów }\end{array}$ & $\begin{array}{l}\text { dwa } \\
- \text { koty } \\
- \text { domy }\end{array}$ & $\begin{array}{l}\text { dwie } \\
\text { lampy }\end{array}$ & $\begin{array}{l}\text { dwa } \\
\text { okna }\end{array}$ \\
\hline $\begin{array}{l}\text { trzej / trzech } \\
\text { profesorowie / profesorów }\end{array}$ & $\begin{array}{l}\text { trzy } \\
- \text { koty } \\
- \text { domy }\end{array}$ & $\begin{array}{l}\text { trzy } \\
\text { lampy }\end{array}$ & $\begin{array}{l}\text { trzy } \\
\text { okna }\end{array}$ \\
\hline $\begin{array}{l}\text { czterej / czterech } \\
\text { profesorowie / profesorów }\end{array}$ & $\begin{array}{l}\text { cztery } \\
- \text { koty } \\
- \text { domy }\end{array}$ & $\begin{array}{l}\text { cztery } \\
\text { lampy }\end{array}$ & $\begin{array}{l}\text { cztery } \\
\text { okna }\end{array}$ \\
\hline
\end{tabular}

Źródło: opracowanie własne

Problem z kategorią męskoosobową w polszczyźnie można uznać za pochodną opisanego wcześniej historycznego zagmatwania wynikającego z liczenia na palcach czy parstach. Dla cudzoziemskiego odbiorcy rzecz cała sprowadza się ponownie do odpowiedzi na pytanie: Kiedy jest, a kiedy są? Bo przecież pojawią się konstrukcje zdaniowe z liczebnikiem, które je wymuszą. Podpowiedzią przekonywającą wielu uczących się jest zwrócenie ich uwagi na intencję wypowiedzi:

* wskazanie tylko na liczbę osób

+ logiczna i gramatyczna liczba mnoga:

To sa dwaj, trzej, czterej panowie, uczniowie...

MIANOWNIK!

** wskazanie również na miejsca - tutaj, tam, w biurze...

a) Tutaj sa dwaj, trzej, czterej panowie... MIANOWNIK!!!

b) Tutaj jest dwóch (dwu), trzech, czterech panów... DOPEŁNIACZ !!!

Nie jest to wyjaśniająca wszystkie wątpliwości podpowiedź, jak to często bywa przy próbach tłumaczenia zaistniałych w języku dualizmów. Dlatego w ślad za nią podążać muszą liczne egzemplifikacje, użycia kontekstowe, a następnie ćwiczenia automatyzujące:

To sa dwaj profesorowie z naszej uczelni. To jest dwóch / dwu profesorów z naszej uczelni.

Tu jest czterech braci Anny. To sa

To są nasi dwaj serdeczni przyjaciele z Rosji. Tu jest dwóch / dwu Rosjan z Władywostoku. 
*Tu spotkałem dwu (dwóch) lekarzy z naszego szpitala.

*Dwaj koledzy Adama interesują się muzyką afrykańską.

*Od dzisiaj jest w naszej grupie dwu (dwóch) nowych studentów.

*Tu pracują trzej inżynierowie z Holandii.

*To jest nas tylko trzech z Warszawy.

*Ostatnio czytałem francuską powieść historyczną Trzej Muszkieterowie, którą napisał Alexandre Dumas...

1. W naszej firmie pracuje (3) specjalistów biochemików.

2. Nie wiesz, kto to jest? To są nasi (2) goście z Senegalu.

3. Ci (2) ministrowie znowu dostali medale od prezydenta.

4. To nie było (2) najlepszych przyjaciól, jakich znałem....

Brnięcie w gramatyczne meandry kategorii męskoosobowej nie stanowi istoty tego wywodu. Należy jednak uzmysłowić cudzoziemskim słuchaczom, że kategoria taka istnieje i zawiła jest jedynie w obrębie liczb 2,3,4. Dalej „kończy się zasięg ręki". Stąd: $d w a j$, trzej, czterej profesorowie obok $d w o ́ c h$, trzech, czterech profesorów - ale już tylko pięciu, sześciu... dwudziestu... profesorów. Tworzenie form męskoosobowych stało się w języku polskim możliwe dzięki wprowadzeniu neologizmów trzej, czterej oraz użyciu w tej funkcji dopełniacza trzech, czterech, a także zróżnicowania form biernika, który tutaj jest identyczny z dopełniaczem, podczas gdy pozostałe kategorie męskie są równe mianownikowi (Długosz-Kurczabowa, Dubisz 1998, s. 250).

No cóż, lepszy wróbel w garści, niż liczebnik na dachu.

\section{BIBLIOGRAFIA}

Arct M., 1917, Stownik staropolski, Kraków.

Arct M., 1919, Stownik polszczyzny XVI wieku, Kraków.

Bańkowski A., 2000, Etymologiczny słownik języka polskiego, t. 1-2, Warszawa.

Brückner A., 1927, Stownik etymologiczny języka polskiego, Kraków.

Długosz-Kurczabowa K., 2008, Wielki stownik etymologiczno-historyczny języka polskiego, Warszawa.

Długosz-Kurczabowa K., Dubisz S., 1998, Gramatyka historyczna języka polskiego, Warszawa.

Garncarek P., 2009, Nie licz na liczebnik, Warszawa.

Siuciak M., 2008, Ksztaltowanie się kategorii gramatycznej liczebnika w języku polskim, Katowice. 


\section{HOW TO COUNT IN POLISH - LINGUACULTURAL ASPECTS OF THE DESCRIPTIVE AND HISTORICAL GRAMMAR OF NUMERALS}

Keywords: linguaculture, grammar of numerals, cultural glottodidactics, teaching, anthropometry

Summary. The article is dedicated to the issue of how to teach the grammar of numerals to foreigners. The article exposes the problem of a dual way of expressing plurality in sentence structures. The author provides the grammatical explanation of the issue provided, in which the nominality of the numerals (lower or higher than 5) determines the nominative or genitive sentence structure. Together with the neurolinguistics interpretation of this mechanism, the text provides also linguacultural reflections which constitute its essence. An anthropomethric explanation and the history of the formation of the linguistic principle are illustrated. Additionally, the text is a particular proposal of an interdisciplinary narrative in teaching the Polish language. 